\title{
KARAKTERISTIK BATUBARA FORMASI TIPUMA DI DAERAH GUNUNG MISEDA RANSIKI DAN INDIKASINYA SEBAGAI KOKAS
}

\author{
Oleh: \\ Dede Ibnu Suhada \\ Pusat Sumber Daya Geologi \\ Jl. Soekarno Hatta No. 444 Bandung
}

\section{SARI}

Batubara daerah Ransiki, Papua Barat menarik untuk diteliti karena berada pada Formasi Tipuma yang berumur Pra-Tersier. Batubara Pra-Tersier ini diharapkan memiliki potensi batubara kokas. Lokasi singkapan batubara ini berada di Gunung Miseda. Calorific Value (CV) dan Free Swelling Index (FSI) digunakan sebagai salah satu parameter batubara kokas. Hasil laboratorium menunjukkan bahwa beberapa conto dari Blok Miseda memiliki kalori 6.403 sampai $7.635 \mathrm{kal} / \mathrm{gr}$ dengan nilai FSI 5 1/2, 6 1/2 dan 7. Nilai-nilai ini mengindikasikan termasuk pada batubara kokas.

Kata kunci; batubara, Formasi Tipuma,Pra-Tersier, batubara kokas, Ransiki, Papua Barat.

\section{ABSTRACT}

Coal of Ransiki, West Papua interested for studying because it lays on the Tipuma Formation of Pre-Tertiary age. This coal has potential as a coking coal. The outcrops are located at Gunung Miseda. Calorific Value (CV) and Free Swelling Index (FSI) were used as parameters to determine the coking coal. The CV of about 6.403 to $7.635 \mathrm{cal} / \mathrm{gram}$ and FSI value of about $51 / 2$, $61 / 2$ and 7 of the sample taken from Miseda Block revealed it as a coking coal.

Keywords; coal, Tipuma Formation, Pre-Tertiary, coking coal, Ransiki, West Papua.

\section{PENDAHULUAN}

Keterdapatan batubara di daerah Ransiki, Papua Barat menjadi hal yang menarik untuk diteliti karena daerah ini didominasi oleh batuan metamorf.

Berdasarkan penelitian Sekolah Tinggi Delft tahun 1955 (Peta Geologi lembar Ransiki) ditemukan batubara dengan tebal 4 meter di sekitar Danau Anggi. Penelitian lainnya dilakukan oleh Hutagalung (1974) dalam Notes on a visit to the Bintuni - Horna Coalfield memfokuskan kepada endapan batubara di daerah Horna yang berada sekitar 30 kilometer ke arah selatan dari Danau Anggi.

Informasi mengenai karakteristik batubara daerah Ransiki yang berumur PraTersier belum banyak diketahui.

Maksud dari penelitian adalah untuk mengetahui karakteristik batubara daerah Ransiki, baik itu sifat fisik maupun kimia dengan tujuan untuk mencari potensi batubara kokas (coking coal).

Batubara kokas menurut kamus McGraw Hill (2003) adalah batubara bituminus yang sangat lembut dan cocok untuk kokas. Sedangkan kokas sendiri berguna dalam peleburan baja yang memerlukan temperatur tinggi.

Hasil penelitian diharapkan memberi informasi awal keberadaan batubara daerah Ransiki yang dalam peta geologi termasuk dalam Formasi Tipuma. Selama ini Formasi Tipuma tidak dikenal sebagai formasi pembawa batubara (coal bearing formation).

Daerah penelitian dapat dicapai dari Ibukota Provinsi Papua Barat, Manokwari melalui arah Ransiki atau dapat juga melalui Manyambou menuju Danau Anggi. Untuk mencapai lokasi singkapan ditempuh dengan berjalan kaki selama dua hari.

\section{GEOLOGI DAERAH PENELITIAN}

Morfologi daerah penelitian sebagian besar adalah morfologi pegunungan curam dengan faktor struktur sangat dominan. Elevasi daerah ini di mulai dari $1.700 \mathrm{~m}$ dpl. sampai $2.660 \mathrm{~m}$ dpl., dengan elevasi tertinggi adalah Gunung Maut. Kemiringan 
lerengnya berkisar antara $20^{\circ}$ sampai lebih dari $65^{\circ}$.

Lembah-lembahnya berbentuk $V$, dengan bentuk punggungan paralel. Sebagian besar pola pengalirannya berupa subtrellis sampai trellis, pola ini mencirikan daerah yang terlipat atau terpengaruh oleh struktur dan juga merupakan ciri dari batuan metamorfik.

Menurut Pieters dkk. (1983) dalam Peta Geologi lembar Ransiki daerah ini termasuk kedalam Bongkah Kemum. Bongkah ini terbangun pada batuan alas yang berumur Silur sampai Devon yang tertindih secara tidak selaras oleh batuan sedimen yang berumur Paleozoikum Atas sampai Tersier
Akhir.

Secara Stratigrafi daerah penelitian sebagian besar didominasi oleh Formasi Kemum (SDk) yang juga merupakan batuan tertua berumur Silur sampai Devon. Formasi ini tersebar di bagian utara sampai bagian timur ke arah selatan. Formasi ini terdiri dari batuan metasedimen tingkat rendah seperti batusabak, serpih sabakan, argilit, batulanau berlapis dengan batupasir dan konglomerat, batuan malihan tingkat menengah sampai tinggi seperti batusabak, filit, batutanduk, batupasir malih, kuarsit, konglomerat malih, sekis, dan genes. Di atas Formasi Kemum diendapkan secara tidak selaras Formasi Tipuma (Trjt).

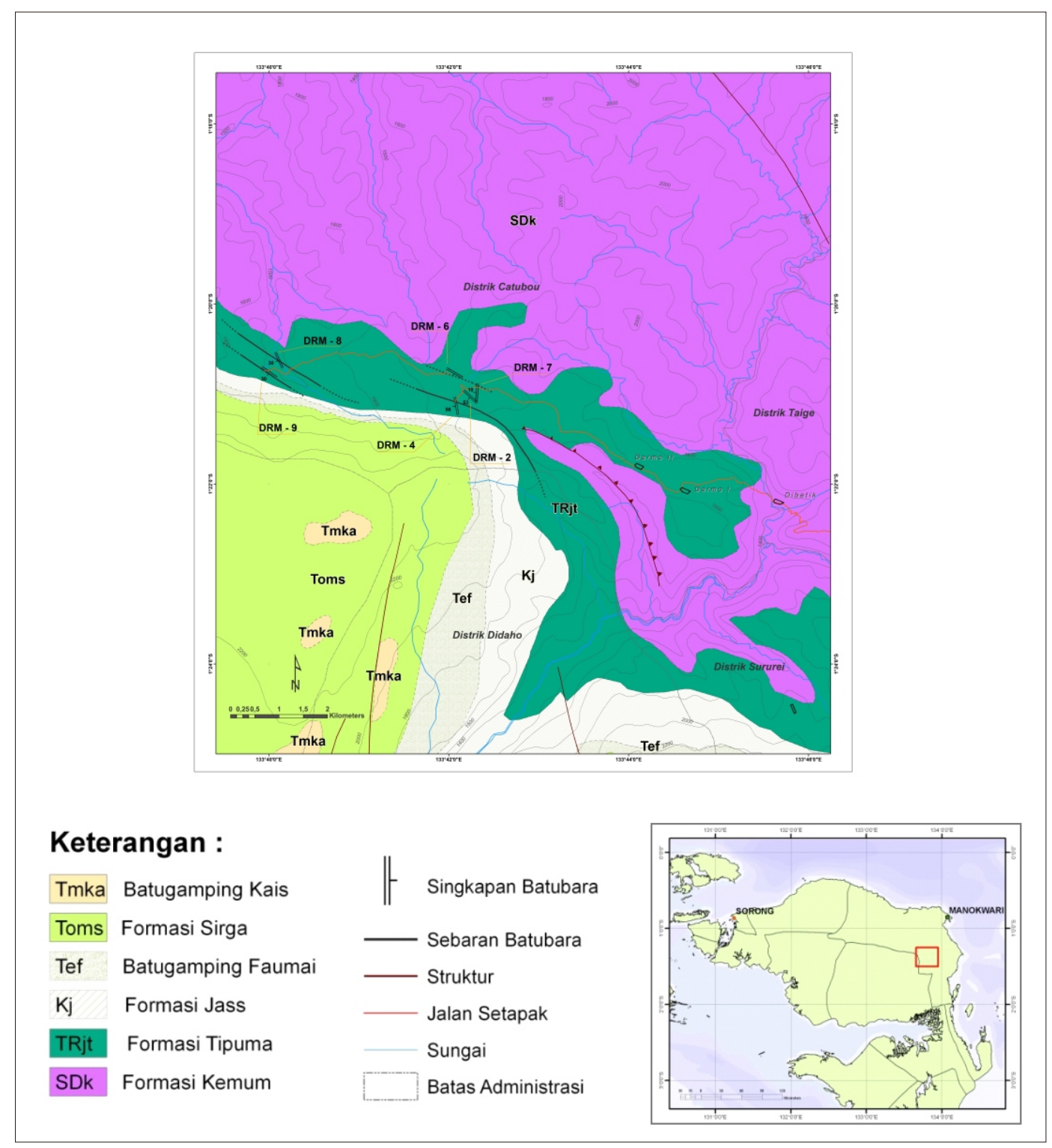

Gambar 1. Peta Geologi dan sebaran batubara Gunung Miseda Ransiki 
Formasi Tipuma tersebar mulai dari bagian barat yaitu Kampung Darmo sampai ke bagian tenggara Distrik Sururei. Di Papua sendiri formasi ini penyebarannya meluas dimulai dari barat laut Kepala Burung sampai ke timur dekat perbatasan. Formasi ini berada pada Cekungan Salawati, Bintuni, Lipatan Lengguru sampai ke Bagian Tengah Kepala Burung. Batuannya terdiri dari batulumpur, batulanau, batupasir, konglomerat, dan batugamping dengan lingkungan pengendapan fluvial dan terjadi selama periode pemisahan benua (continental rifting) (Piagram and Panggabean, 1983 dalam The Geology of Indonesia, 2000). Berdasarkan posisi stratigrafinya umur formasi ini adalah Trias sampai Jura bagian bawah.

Formasi Jass (Kj) diendapkan secara tidak selaras diatas Formasi Tipuma, terdiri dari batupasir gampingan, batulumpur, batulanau, sedikit batunapal, kalsilutit, kalkarenit pasiran, dan konglomerat. Di atasnya diendapkan secara selaras Batugamping Faumai (Tef), terdiri dari biokalkarenit, biokalsilutit, serpih gampingan, batugamping dolomitan, dengan penyebaran berada di sebelah selatan daerah penelitian.

Formasi Sirga diendapkan pada Oligosen bagian atas sampai Miosen bagian bawah, penyebarannya berada di sebelah selatan, terdiri dari batupasir kuarsa, batulumpur dan kalkarenit. Kemudian diendapkan Batugamping Kais (Tmka) yang penyebarannya setempat-setempat yaitu di Tiraga dan Siahara atau di sebelah baratdaya daerah penelitian. Batugamping ini terdiri dari biokalsilutit, biokalkarenit dan batugamping terumbu dengan penyebaran yang luas berada di sebelah selatan lokasi penelitian, termasuk ke dalam Cekungan Bintuni.

Secara umum daerah penelitian termasuk kedalam sistem Sesar Ransiki, sesar aktif ini berada di timur daerah penelitian berarah relatif utara-selatan. Kemunculan dua danau kembar (Danau Anggi Gigi dan Anggi Gida) diperkirakan merupakan bagian dari depresi sesar ini. Bagian lain dari sesar ini dimulai dari Sungai Prafi di Manokwari kemudian ke Manyambou lalu menerus melalui Sungai
Warjori dan memotong Danau Anggi Gigi. Di bagian barat, yaitu di Distrik Didohu dan Catubou muncul sesar berarah relatif barat timur, yang menyebabkan longsor pada daerah sekitarnya.

\section{HASIL DAN ANALISIS}

Di Gunung Miseda, sekitar lima kilometer dari Kampung Darmo ke arah barat sampai ke Distrik Didohu terdapat blok batubara. Batubara ini berwarna hitam, kilap terang, padu, ringan, tidak mengotori tangan. Secara regional batubara ini berada pada Formasi Tipuma (Trjt) yang berumur Trias.

Lapisan batubara memiliki arah jurus perlapisan berkisar antara $\mathrm{N} 115^{\circ} \mathrm{E}$ sampai $\mathrm{N} 125^{\circ} \mathrm{E}$ dengan kemiringan berkisar $10^{\circ}$ sampai $30^{\circ}$. Sebagian singkapan berada pada zona hancuran dan juga deformasi yang menyebabkan arah lapisan berubahubah dengan kemiringan hampir tegak seperti pada singkapan DRM-2 dan DRM-4 (Tabel 1.).

Di lokasi DMR-7 dan DMR-9, dalam satu singkapan terdapat beberapa lapisan tipis batubara mulai dari 2 - $40 \mathrm{~cm}$ dengan lapisan pengapit berupa batupasir yang cukup keras. Penyebaran batubara antara DRM-3 dengan DRM-8 sejauh lima kilometer, kemungkinan menerus ke arah barat Kampung Testega.

Hasil analisis laboratorium (Tabel 2) batubara di Gunung Miseda menunjukkan nilai kalori mulai dari $6.403-7.635 \mathrm{kal} / \mathrm{gr}$ dengan rata-rata $7.323 \mathrm{kal} / \mathrm{gr}$. Nilai lainnya seperti kandungan air melekat (M) berkisar dari 3,43-5,13\%, zat terbang (VM) 39,99 $48,83 \%$, karbon tetap (FC) 39,45 - 50,46\%, kandungan abu (ash) 0,49-17,44\%, Sulfur 0,99-2,85\%, dan HGI berkisar 21-32.

Hasil analisis petrografi (Tabel 3) terdiri dari tiga kelompok maseral yaitu: vitrinit, inertinit dan liptinit. Vitrinit merupakan maseral yang dominan, diikuti inertinit dan sedikit liptinit. Inertinit hadir sekitar $3-5 \%$. Nilai reflektan vitrinit batubara Gunung Miseda berkisar 0,39-0,54\%.

\section{PEMBAHASAN}

Batubara di Gunung Miseda merupakan batubara kalori sangat tinggi. Hasil analisis laboratorium untuk beberapa conto batuan memiliki nilai FSI (free swelling index) atau 
Tabel 1

Daftar singkapan batubara Gn. Miseda Ransiki

\begin{tabular}{|c|c|c|c|c|c|c|c|}
\hline Stasiun & BT & LS & $\begin{array}{c}\mathrm{Z} \\
\text { (meter) }\end{array}$ & Strike & Dip & $\begin{array}{l}\text { Tebal } \\
\text { (meter) }\end{array}$ & Ket. \\
\hline DRM-1 & $133^{\circ} 42^{\prime} 23,7^{\prime \prime}$ & $1^{\circ} 20^{\prime} 57,2^{\prime \prime}$ & 2113 & - & - & - & $\begin{array}{l}\text { Fragmen } \\
\text { Batubara }\end{array}$ \\
\hline DRM-2 & $133^{\circ} 42^{\prime} 18,3^{\prime \prime}$ & $1^{\circ} 20^{\prime} 55,8^{\prime \prime}$ & 2105 & 184 & 53 & 0,20 & Batubara \\
\hline DRM-3 & $133^{\circ} 42^{\prime} 11,5^{\prime \prime}$ & $1^{\circ} 21^{\prime} 00,3^{\prime \prime}$ & - & - & - & - & Batubara \\
\hline DRM-4 & $133^{\circ} 42^{\prime} 03,6^{\prime \prime}$ & $1^{\circ} 21^{\prime} 05,0 "$ & 2073 & 170 & 86 & 0,10 & Batubara \\
\hline DRM-6 & $133^{\circ} 41^{\prime} 49,8^{\prime \prime}$ & $1^{\circ} 20^{\prime} 46,1^{\prime \prime}$ & 2084 & - & - & $\begin{array}{l}0,01 \\
0,02 \\
0,02 \\
0,02\end{array}$ & $\begin{array}{l}\text { Lensa tipis } \\
\text { batubara }\end{array}$ \\
\hline DRM-7 & $133^{\circ} 42^{\prime} 00,6^{\prime \prime}$ & $1^{\circ} 20^{\prime} 45,6^{\prime \prime}$ & 2084 & 120 & 10 & $\begin{array}{l}0,05 \\
0,01 \\
0,04 \\
0,04 \\
0,02 \\
0,04\end{array}$ & Batubara \\
\hline DRM-8 & $133^{\circ} 40^{\prime} 7,6^{\prime \prime}$ & $1^{\circ} 20^{\prime} 38,8^{\prime \prime}$ & 1636 & 115 & 30 & 0,40 & Batubara \\
\hline DRM-9 & $133^{\circ} 40^{\prime} 03,6^{\prime \prime}$ & $1^{\circ} 20^{\prime} 42,8^{\prime \prime}$ & 1581 & 125 & 30 & $\begin{array}{l}0,06 \\
0,06 \\
0,03 \\
0,01 \\
0,10\end{array}$ & Batubara \\
\hline
\end{tabular}

Tabel 2.

Hasil analisis proximate batubara Gn. Miseda Ransiki

\begin{tabular}{|c|c|c|c|c|c|c|c|c|}
\multicolumn{3}{|c}{ ANALYSIS UNIT } & BASIS & \multicolumn{7}{c|}{ Sample Code } \\
\cline { 5 - 10 } & & DRM-2 & DRM-3 & DRM-4 & DRM-7A & DRM-7B & DRM-9 \\
\hline PROXIMATE & & & & & & & & \\
\hline M & $\%$ & adb & 5.13 & 3.43 & 4.96 & 4.37 & 3.12 & 4.29 \\
\hline VM & $\%$ & adb & 43.33 & 48.48 & 46.70 & 46.13 & 39.99 & 48.83 \\
\hline FC & $\%$ & adb & 50.46 & 43.79 & 45.23 & 47.57 & 39.45 & 46.39 \\
\hline ASH & $\%$ & adb & 1.08 & 4.30 & 3.11 & 1.93 & 17.44 & 0.49 \\
\hline St & $\%$ & adb & 1.69 & 2.73 & 2.85 & 0.99 & 1.25 & 2.40 \\
\hline HGI & & adb & - & 30 & 21 & - & 32 & - \\
\hline RD & & adb & 1.30 & 1.32 & 1.30 & 1.30 & 1.41 & 1.30 \\
\hline FSI/CSN & & adb & $21 / 2$ & $61 / 2$ & 7 & 3 & $11 / 2$ & $51 / 2$ \\
\hline CV & Cal/gr & adb & 7375 & 7472 & 7497 & 7558 & 6403 & 7635 \\
\hline
\end{tabular}


Tabel 3.

Hasil analisis petrografi batubara Gn. Miseda Ransiki

\begin{tabular}{|c|c|c|c|c|c|c|c|c|}
\hline \multirow[t]{2}{*}{ No Conto } & \multirow{2}{*}{$\begin{array}{c}\text { Reflektan } \\
\text { Vitrinit } \\
\left(\% \mathbf{R} \mathbf{v}_{\max }\right)\end{array}$} & \multirow[t]{2}{*}{$\begin{array}{c}\text { Kisaran } \\
(\%)\end{array}$} & \multicolumn{3}{|c|}{$\begin{array}{c}\text { Komp. Maseral } \\
(\%)\end{array}$} & \multicolumn{3}{|c|}{ Material Mineral (\%) } \\
\hline & & & $\mathbf{V}$ & 1 & $\mathbf{L}$ & Clay & OxB & PY \\
\hline DRM-2 & 0,4546 & $0,39-0,52$ & 92,6 & 4,5 & 0,5 & 1,9 & 0,4 & 0,1 \\
\hline DRM-3 & 0,4416 & $0,40-0,48$ & 92,5 & 3,9 & 0,4 & 2,8 & 0,2 & 0,2 \\
\hline DRM-4 & 0,4015 & $0,34-0,42$ & 90,3 & 5,2 & 0,4 & 2,2 & 0,4 & 1,5 \\
\hline DRM-7A & 0,4715 & $0,40-0,54$ & 90,6 & 7,7 & 0,3 & 1,2 & 0,1 & 0,1 \\
\hline DRM-7B & 0,4369 & $0,37-0,49$ & 90,6 & 4,6 & 0,2 & 1,1 & 0,1 & 0,1 \\
\hline DRM-9 & 0,4536 & $0,43-0,49$ & 94,8 & 4,4 & 0,3 & 0,3 & 0,1 & 0,1 \\
\hline
\end{tabular}

CSN (crucible swelling number) tinggi yaitu $5 \frac{1}{2}, 6 \frac{1}{2}$, dan 7. Menurut Blayden, (1982) berdasarkan hubungan porositas dengan kekuatannya, nilai kisaran FSI 5 sampai 8 merupakan nilai yang sangat bagus untuk batubara kokas (coking coal).

Selain FSI terdapat beberapa parameter lainnya untuk menentukan tipe batubara kokas diantaranya adalah Gray King Coke Type, Audibert-Arnu Dilatometer Test, dan Gieseler Plastometer Test (Blayden, 1982).

Hal menarik dari batubara Ransiki adalah tingkat kematangan vitrinite $\left(\mathrm{RV}_{\text {max }}\right)$ yang berkisar dari $0,34-0,52 \%$, jika dibandingkan dengan nilai kalorinya, maka nilai $\mathrm{RV}_{\text {max }}$ tersebut tidak menunjukkan batubara kalori sangat tinggi, sedangkan menurut Cook (2008) $\mathrm{RV}_{\text {max }}$ batubara kokas berkisar antara 1,7-1,9\%.

\section{KESIMPULAN}

Sebagian batubara di Ransiki memiliki nilai $\mathrm{FSI} / \mathrm{CSN}>1$ yang merupakan indikasi batubara kokas. Akan tetapi nilai $\mathrm{RV}_{\text {max }}$ nya tidak menunjukkan indikasi batubara kokas sehingga untuk memperkuat analisis diperlukan pengujian dengan parameter lain.

\section{UCAPAN TERIMAKASIH}

Penulis mengucapkan terimakasih kepada Ir. Asep Suryana yang memberikan saran dan masukan sehinga makalah ini dapat terselesaikan. 


\section{DAFTAR PUSTAKA}

Anonim, 1998, Klasifikasi Sumberdaya dan Cadangan Batubara, Badan Standarisasi Nasional, Jakarta.

Blayden, I.D. \& Goodwin, P.W., 1982, Coal Basin Exploration-Strategies, Methods, Analytical Programmes and Case Histories, University of Wollongong, Australia.

Cook, A.C., 2008, Coking Coals, with special reference to coking coals from Indonesia, Keiraville Konsultans NSW Australia.

Darman, H. \& Sidi, H, 2000. An Outline of The Geology of Indonesia, IAGI, Jakarta.

Hutagalung J.S.O., 1974, Report No.112 Notes on a Visit to the Bintuni - Horna Coalfield Vogelkop Irian Jaya, PT Riotinto Bethlehem Indonesia, Jakarta

McGraw-Hill Science \& Technology Dictionary, 2011, http://www.answers.com/topic/cokingcoal, diakses tanggal 30 Oktober 2011

Pigram C.J. \& Sukanta U., 1989; Geologi Lembar Taminabuan Skala 1 : 250.000. Pusat Penelitian dan Pengembangan Geologi, Bandung.

Pieters P.E., Hakim A. S., Atmawinata S., 1990, Geologi Lembar Ransiki, Irian Jaya, Pusat Penelitian dan Pengembangan Geologi, Bandung 